TITLE: BIOLOGICAL INTRUSION OF LOW-LEVEL-WASTF. TRENCH COVERS

1 AUTHOR(S): T.F. Hakonson

E.S. Gladney

SUBMITTED TO: Proc. Symposia On Nuclear Waste Manageinent (November 17-19, 1981)
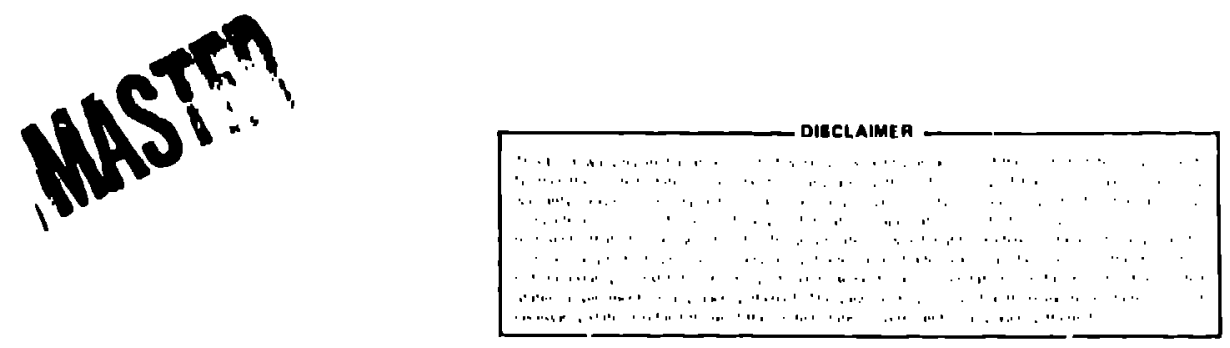

Byecoplance of inis arlicle, the publishel recognizes this: the

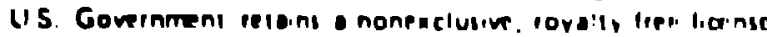
to publish of epproduce the Dutlished forin of inis conlilis lion. of 10 ellow olinen 10 do so, lor U.5 Govermenl pur pones

The Los Alames Sctentific Laboralniy reuue:ts tive the pub lishel idenlity this ellicle an work perlormed under int ous pices of phe US Deperiment of Enefor 


\title{
BIOLOGICAL INTRUSION OF LOW-LEVEL WASTE TRENCH COVERS
}

\author{
THOMAS E. HAKONSON AND ERNEST S. GLADNEY \\ Environmental Science Group, Los Alamos National Laboratory, Los Alamos New Mexico, USA
}

\begin{abstract}
The long-term integrity of low-level waste shallow land burial sites is dependent on the intersction of physical, chemical, and biological factors that modify the waste containment system. Past research on low-level waste shallow land burial methods has emphasized physical (i.e., water infiltration, soil erosion) and chemical (radionuclide leaching) processes that can cause waste site failure and subsequent radionuclide transport.

The purpose of this paper is to demonstrate the need to consider biological processes as being potentially important in reducing the integrity of waste burial site cover treatments. Plants and animals not only can uranspor radionuclides to the ground surface via root systems and soil excavated from the cover profile by animal burrowing activities, but they modify physical and chemical processes within the cover profile by changing the water infiltration rates, soil erosion rates and chemical composition of the soii.

One approach to limiting biological intrusion through the waste cover is to apply a barrier within the profile to limit root and animal penetration with depth. Experiments in the Los Alamos Experimental Engineered Test Facility were initiated to develop and evalugte bıological barriers that are effective in minimizing intrusion into waste trenches. The experiments that are described employ four different candidate barrier materials of geologic origin. Experimental variables that will be eva'uated, in addition to barrier type, are barrier depth and soil overburden depth. The rate of biological intrusion through the various barrier materials is being evaiuated through the use of activatable stable tracers.
\end{abstract}

\section{INTRODUCTION}

Low-activity and wastes suspected of being contaminated are generally buried in shallow t:enches (1.5 $1045 \mathrm{~m}$ wide, 2 to $11 \mathrm{~m}$ deep, 6 to $300 \mathrm{~m}$ long) that are covered with from less than 1.0 to $2.5 \mathrm{~m}$ of material when the trenches are full (Duguid, 1977). Most waste burial facilities attempt to revegetate the trench covers to minimize soil loss and to increase aesthetic appearance of the site. Although it has been recognized (Lutton et al., 1979; Anonymous, 1979) that biological intrusion of low-level waste trenches can lead to transport of radionuclides from a burial site, little has heen done to quantify the magnitude of the problem and to develop measures, when needed, to prevent the intrusion.

The stability of low-level waste trench covers is a function of physical, chemical, biological, and climatological factors that interact in both obyious and subtle ways. The importance of biological factors in altering the integrity of trench covers is often overlooked despite evidence that plants and animals can influence trench corer stability and. as well, can mobilize radionuclides buried in the trench (Lutton et al., 1979; Anonymous, 1979). Biological interactions with trench covers can be direct, ac in the case of radionuclide uptake by plant roots, or they can be indirect, such as when cunnel systems cieated by burrowing animals increase the rates and depths of rain water penetration into the trench cover profile.

The nurpuse of this paper is to review biologicai relationships within the soil profile that can and do impact lowlevel waste trench covers. Experiments at the Los Alamos Experimental Engineered Tcst Facility that evaluate the effectiveness of several geologic materials in minimizing biological in:rusion through low level waste trench covers are also described.

\section{BIOLOGICAL INTERACTIOINS WITH WASTE COVERS}

The absence or presence of vegetation on a low-level waste site cover has an important influence on the pro:esses that may transport iadionuclides from a low-level waste site. The influence can be both positive or negative in relation to radionuclide transport. Positive benefits of dense vegetation cover include the interception of precipitation by plent surfaces, which prevents much of the water daposited by light atorms from ever reaching the ground surface 
(Enlow and Musgrave, 1938). Additionally, interception of raindrops by plant canopies decreases raindrop impact velocities at the ground surface thereby reducing diaggregation and erosion of soil particles. Vegetation and erosion aiso retard water flow by decreasing overland flow velocities and can reduce runoff by increasing infiltration capacity. Another benefit derived by vegetative cover on a waste site is that plants use moisture from within the cover profile thereby reducing depthi of water penctration into the waste trenches.

In contrast, plant roots have the potential of mobilizing radionuclides buried in the trench. As previously mentioned, trench covers are generally less than $2.5 \mathrm{~m}$ in depth. Cover depths of $2.5 \mathrm{~m}$ or less are easily penetrated by the root systems of many agricultural ind native plant species. For example, native plants growing on low-level waste sites at Hanford and Los Alamos show tlevated levels of certain radionuclides (Klepper et al., 1979; Dubrowskj, 1973; Hakonson and Bostick, 1976).

The natural phenomenon of plant succession on low-level waste sites presents some special problems that require consideration. Despite the fact that most trench covers are reseeded with vegetation as a final step in trench closure, the species growine on the waste cover can be expected to change with time. For example, at Los Alamos the vegetation growing on sites closed within the last 5 years consists primarily of native wads that invaded the site following site closure. At sites clesed about 20 years ago, the vegetation is deminated by smali sirubs, while at sites closed about 35 years ago, the vegetation consists of large shrubs and trees. Most of these species, regardless of growth form, have the potential for sending root systems through the shallow cover profiles normally used at low level waste sites (Table I). Waste covers are especially susceptible to penetretion by plant roots because cover soils are usually lorsely coinpacted and have high water retention properties.

\section{TABLE I}

\section{ROOTING DEPTHSOF NATIVE PLANTS}

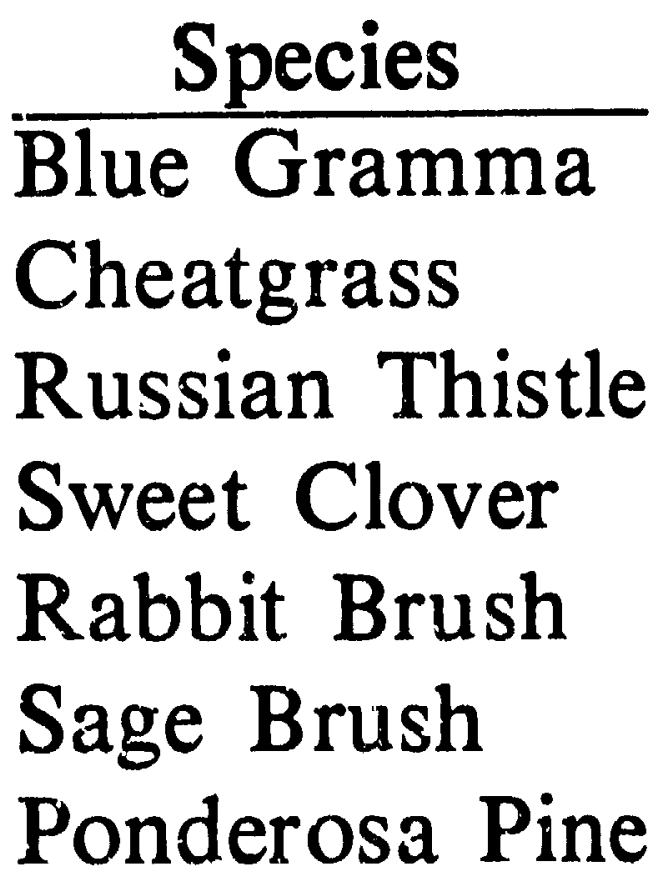

Root Depth

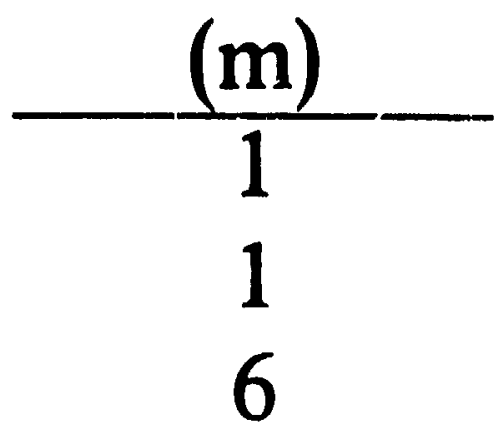

$5-10$

$<5$

$<5$

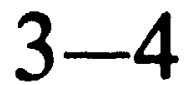


Intrusion of low-level waste covers by burrowing animals is a little understood or appreciated phenomenon despit. evidence that long term stability of soil profiles can be altered by burrowing animals. For example, jack rabbits at th. Hanford Reservation in Washington burrowed into a waste site cover and gained access to buriec radioactive salt (O'Farrell and Gilbert, 1975).

Not only do anima's access radioactive waste buried in trenches, but their burrowing activity greatly alter physical and chemical relationships in the soil profile. For example, tunnel construction by pocket gophers can resul in the excavation of as much as 60 metric tons of soil per hectare of zround surface each year (Thorpe, 1949). I some areas, pocket gopheris turn over 15 to $20 \%$ of the soil surface in a single year.

Studies at Los Alamos have shown that pocket gophers inhabiting a low level waste site excavated about 12 metri. tons $\mathrm{ha}^{-1} \mathrm{yr}^{-1}$ of soil from within the cover profile as a result of tunneling activities. The void created by this mass 0 soil represents about $2800 \mathrm{~m}$ of tunel system in the 1 ha area.

The existence of animal tunnel systems within the soil profile has important effects on soil erosion and soil moistur cycling. For t:xample, cast soil is subject to higher erosion rates than vegetated soil surfaces (Ellison. 1946) Additionally, the void created by tunnel systems enhances the rates of water infiltration (Grinnel, 1923). Wate infiltration rates over pocket gopher mound systems was found to be twice as high as over undisturbeci native rang (Grant, 1974).

\section{INTRUSION BARRIER STUDIES}

A series of experiments was initiated at Los Alamos in the Experimental Engineered Test Facility to lest th effectiveness of several natural geclogic materials as barriers that inhibit plani and animal intrusion into low-leve waste cover profiles. Initial experiments employ 320 weighing lysimeters consisting of $25 \mathrm{~cm}$ diameter PVC pip. ranging frum 105 to $2 \mathrm{i} 0 \mathrm{~cm}$ in length. Experimental cover profiles were constructed in the lysimeters to evaluate th effect of four different variables on plant root penetration with depth. The profiles, as shown by the example in Fig. 1 consist of a simulated waste $(\mathrm{CsCl})$ at the bottom of the profile. The waste layer is overlain by a barrier laye consisting of four different types of natural geologic materials (cobble, cobble-gravel, bentonite clay, and crushed tuf at three different depths. Top soil is applied at two different depths as an overburden to complete the profiles. Thre species of fast-growing, deep-rooted plants (alfalfa, barley, yellow sweet clover) were seeded into the lysimeters t produce the biological stress for evaluating the barrier systems.

A companion study was also initiated to evalute the effectiveness of the barrier systems in inhibiting anima burrowing with depth. Four galvanized metal culverts $(1.9 \mathrm{~m}$ diameter by $2.2 \mathrm{~m}$ height) were filled with a experimental waste cover profile consisting of each of the bio-barrier matericls overlain by top soil. A pocket gophe (Thomomys bottae), a highly active burrowing animal, was irtroduced into each culvert system and was allowed t1 construct a burrow system within the cover profile. The succes; or 'ailure of the barriers will be evaluated $b$ : analyzing plant tissue for stable cesium, using a neutron activation analysis, throughou: the growing season in th case of the lysimeter study, and by physically mapping the plant root and animal burrow systems in the cover profile at the conclusion of the experiment.

The biological intrusion barries studies are one of several studes being conducted in the Los Alanos Experimenta Engineered Test Facility. The purpose of these studics is to derign and evaluate integrated barrier systems that ar effective in iimiting erosion, moisture infiltration, and biologicai intrusion of low level waste cover profiles.

\section{ACKNOWLEDGMENTS}

This work was funded by the Department of Energy unde $r$ contriet W-7405-ENG -36 with Los Alamos Nationa Laboratory. Special thanks to E. Montoya, M. Lewis, L. Martinex, E. Karlen, D. Mclnroy, and K. Bostick fo assisting with various phases of this Hork. 


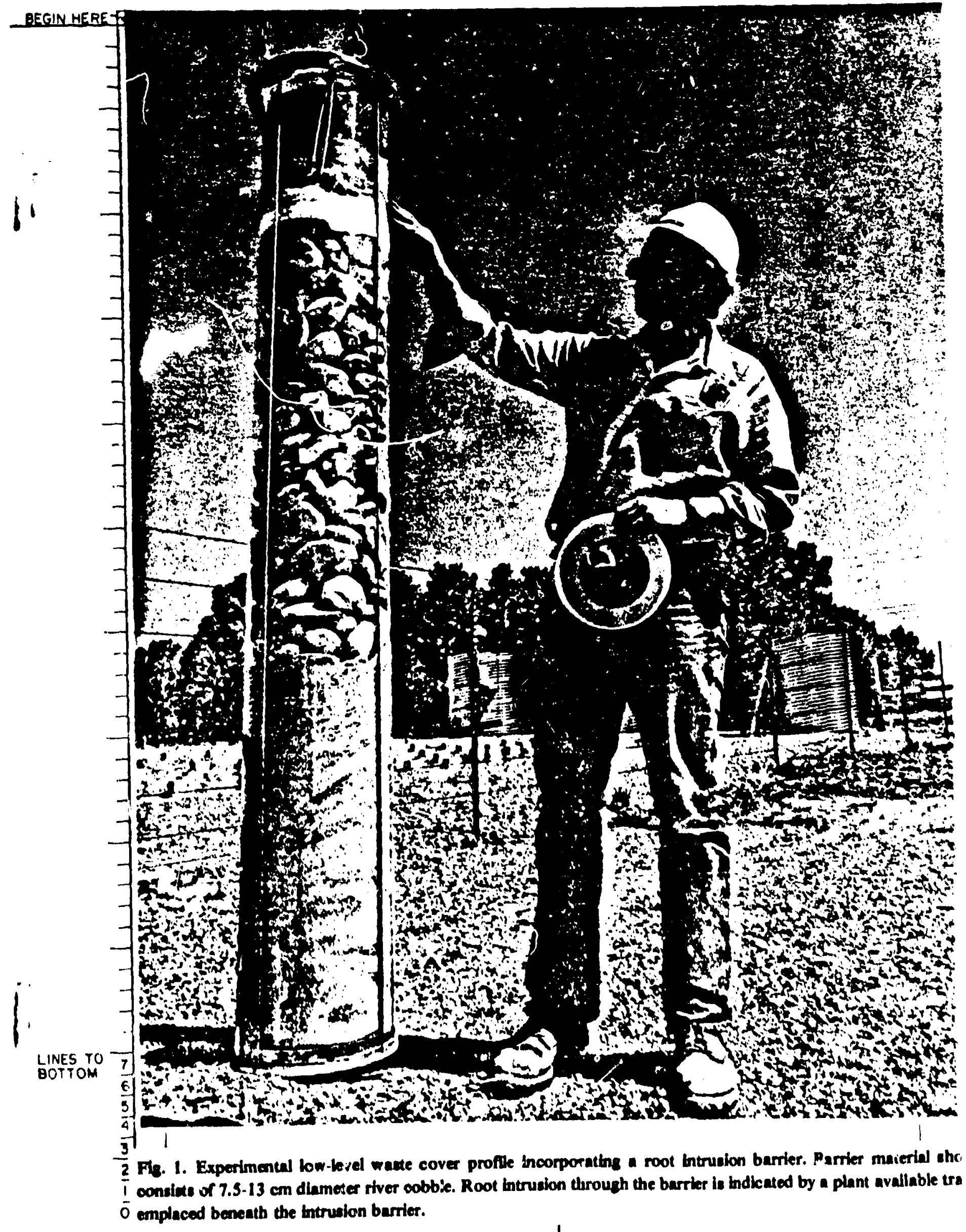




\section{LITERATURE CITED}

Anonymous "Unresolved Technical Issues in Land Burial of Low-Level Rdioactive Waste," Oak Ridge National Laboratory report ORNL/NFW-79/62 (1979).

T. E. Dabrowski, "Radioactive Tumbleweeds in the 100 Areas," Richland, Washingtor: United Nuclear Indusiries report UN1-65 (1973).

J. O. Duguid, “Assessment of DOE Low-Level Radioactive Solid Waste Disposal Storage Activities," Battelle Columbus Latoratories report BMI-1984, 48 pp (1977).

C. R. Enlow and G. W. Musgrave, "Grass and Other Thick-Growing Vegetation in Erosion Conirol," in Soils and Men, Yearbook of Agriculture, Washington, D.C.:USDA, pp. 615-633 (1938).

L. Ellison, "The Pocket Gopher in Relation to Soil Erosion in Mountain Range," Ecology 27:101-114 (1946).

W. E. Grant, "The Functional Role of Sniall Mammals in Grassland Ecosystems," Ph.D. thesis. Colorado State University, Fort Collins, Colorado.

J. Grinuel, "The Burrowing Rodents of California as Agents in Soil Formation," J. Mammal. 14:1?7-148 (1923).

T. E. Hakonson and K. V. Bostick, "The Availability of Environmental Radicactivity to Honey Bee Colonies at Los Alamos," J. Environ. Qual. s:307-310 (1976).

E. L. Klepper, L. E. Rogers, J. D. Hedland, and R. G. Sclireckhise, "Radioactivity Associated with Biota and Soils of the 216-A-24 Crib," Pacific Northwest Laboratory report PNL-1948-UC-70 (1979).

R. J. Lutton, G. L. Regan, and I.. W. Jones, "Design and Construction of Covers for Solid Waste Landfills," Environmental Protection Agency -eport EP. -600/2-79-165 (1979).

T. P. O'Farrell and R. O. Gilt irt, "Transport of Radioactive Materials by Jack Rabbits on the Hanford Reservation," Health Phys. 29:9-5 (1975).

J. Thorp, "Efrects of Certuin Animals, That Live in Scils," Sci. Monthly 68:180-191 (1949). 